\title{
Monitoring of water quality in Ciujung river using remote sensing and GIS
}

\author{
Shofiyatul Afidah*, Sutrisno Anggoro, Sudarno \\ Magister Program of Environmental Science, School of Post-Graduate, Diponegoro University, \\ Semarang - Indonesia
}

\begin{abstract}
Ciujung River is one of the important rivers in Banten Province and it is the main water supply for agriculture, industry and bathing. Due to extensive agricultural, urban, and industrial activities in the watershed of this ecosystem, some studies have assumed that the river is contaminated. But, there is no research related Ciujung River water quality with biological indicator and maping pollutant sources. The aim of this study is analyze : water quality of Ciujung River and influence of activities in Ciujung watershed to the water pollution in Ciujung River. Calculation Pollution Index (PI) and calculation chlorophyll-a abundance are adopted for water quality assessments. Water quality were analysed based on secondary data from BBWS C3 in January-May 2020. Chlorophyll-a abundance measured by Sentinel-2 imagery, water quality assessments result of each section presented in spasial data with GIS. Water quality map overlayed with land use map to indentify the influence of activities in Ciujung watershed to water pollution in Ciujung River. PI calculation results show that Ciujung River is moderately polluted, PI calculation result of each section is $>5$. Meanwhile, the abundance of chlorophyll-a can describe level of pollution in Ciujung River from biological parameters, the highest chlorophyll-a abundance is in Pamarayan $(38,6)$ and the lowest chlorophyll-a abundance is in Jembatan Keong $(18,6)$.
\end{abstract}

Keywords. Ciujung river, GIS, remote sensing

\section{Introduction}

River water pollution has many attention and continues to receive serious concern throughout the world. Water quality deterioration is an impact of population growth and rapid city development. Poor water quality give out bad impact to human and ecological health [1]. Ciujung River is one of polluted river in banten, it has been proven by Hindriani in 2013 and Andini in 2017. That studies can only describe Ciujung water pollution from physic and chemical parameters. Physic and chemical parameters can only describe water quality at certain times, while biological indicators can monitor continuously and easy guide to monitor

\footnotetext{
* Corresponding author: shofiyatul.afidah@gmail.com
} 
the occurence of pollution. The existence of aquatic organism can be used an indicator of water pollution [2].

Chlorophyll-a (Chl-a) can describe the trophic status of aquatic [3]. In-situ water samples and chemical analysis have many disadvantage: the large spatial and temporal scales of sampling coverage is still limited, both sampling and chemical analysis are costly and timeconsuming [4]. Remote sensing has been widely used to monitoring water quality such as abundace of chlorophyll-a, remote sensing has shown high reliability in water quality measurements [5].

Pollution Index is calculated to assess the level of water pollution. Pollution Index is determined by comparing simulation data to water quality standards [6]. Many methods have been developed in controlling river pollution combined with GIS to determine the source of pollution [7]. GIS is a device for combining cartography with data-based technology, this information system can present, describe and manage various data sets such as maps of watershed, rivers and marine that are linked to location [8]. The aim of this study is analyze water quality of Ciujung River and influence of activities in Ciujung watershed to the water pollution in Ciujung River.

\section{Study area}

The Ciujung River is located in Lebak Regency and Serang Regency, Banten Province. The length of Ciujung River is 147,2 km. Ciujung River is one of the important rivers in Banten Province and the water of Ciujung River is main water supply for agriculture, industry and bathing.

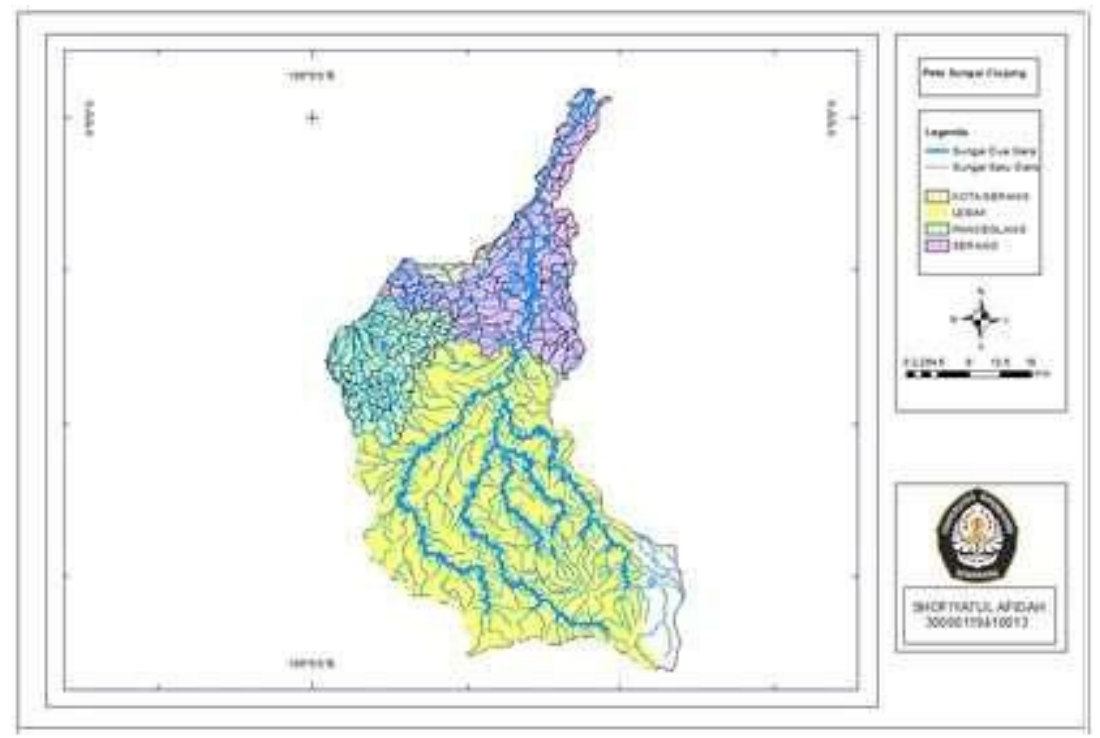

Fig.1. Map of Ciujung River Basin

\section{Methodology}

Water quality were analysed based on secondary data from BBWS C3 (Balai Besar Wilayah Sungai Ciujung, Cidurian dan Cidanau) from January - May 2020. Pollution Index (PI) was conducted to determine water quality status in Ciujung River, PI is function of $\mathrm{Ci} / \mathrm{Lij}, \mathrm{Ci}$ is 
concentration of water quality parameter, Lij is water quality standards (Permen LH 82/2001). Algorithm from Permen LH 82/2001 were used to determine Ci/Lij:

a. DO parameter

$$
C i / L i j=\frac{C i m-C i}{C i m-L i j}
$$

Cim is saturated DO concentration in $25^{\circ} \mathrm{C}$

b. Lij has a range

- $\quad \mathrm{Ci} \leq$ mean of Lij

$$
C i / L i j=\frac{C i-\text { mean of } L i j}{\text { Lijminimum-mean of } L i j}
$$

- $\quad \mathrm{Ci}>$ mean of Lij

$$
C i / L i j=\frac{C i-\text { mean of } L i j}{\text { Lijmaximum-mean of } L i j}
$$

c. If result of $\mathrm{Ci} / \mathrm{Lij}$ calculation is $>1$, should be calculate new $\mathrm{Ci} / \mathrm{Lij}$

$$
(\mathrm{Ci} / \mathrm{Lij})_{\text {new }}=1+\mathrm{P} \log (\mathrm{Ci} / \mathrm{Lij})_{\text {calculation }}
$$

$\mathrm{P}$ is a constanta (usually used 5)

d. After calculated $\mathrm{Ci} / \mathrm{Lij}$ then determine $\mathrm{Ci} / \mathrm{Lij}$ maximum(Ci/Lij)M and mean of $\mathrm{Ci} / \mathrm{Lij}$ (Ci/Lij)R.

e. Calculate Pollution Index (IP)

$$
I P=\sqrt{\frac{\left(\left(\frac{C i}{L i j}\right) M\right)^{2}+\left(\left(\frac{C i}{L i j}\right) R\right)^{2}}{2}}
$$

Evaluation of IP:

Table 1. Evaluation of IP

\begin{tabular}{|l|l|}
\hline \multicolumn{1}{|c|}{ IP } & \multicolumn{1}{c|}{ Information } \\
\hline $0 \leq \mathrm{IP} \leq 1$ & good condition $(\mathrm{G})$ \\
\hline $1 \leq \mathrm{IP} \leq 5$ & light polluted (L) \\
\hline $5 \leq \mathrm{IP} \leq 10$ & moderately polluted (M) \\
\hline $\mathrm{IP}>10$ & heavy polluted $(\mathrm{H})$ \\
\hline
\end{tabular}

Chlorophyll-a abundance measured by Sentinel-2 imagery from January - May 2020 with cloud cover 20\%. Atmospheric correction used QGIS software. Calculation chlorophyll-a abundance used algorithm from [9]:

$$
\begin{aligned}
& \text { Chla }=25,985 \times 3,117 \\
& X=\frac{\operatorname{Rrs}(B 5)}{\operatorname{Rrs}(B 4)}
\end{aligned}
$$


GIS is used to represented the spasial water quality distribution, water quality were mapped out using ArcGIS 10.4 software.

\section{Result and discussion}

\subsection{Pollution Index (IP)}

Pollution Index calculation based on secondary data from BBWS C3 start from January until May 2020 in 10 location:

Table 2. Sampling Location

\begin{tabular}{|c|c|c|}
\hline Location & Coordinate & \\
\hline Bojongmanik (C1) & S: 6034'32,79”' & E:106010’9,39”' \\
\hline Leuwidamar (C2) & S: 6030'49,12”' & $\mathrm{E}: 106^{0} 11^{\prime} 37,21^{\prime \prime}$ \\
\hline Cilaki Jahe (C3) & S: $6^{0} 25^{\prime} 46,77^{\prime \prime}$ & E: $106^{0} 14^{\prime} 27,30$ \\
\hline Sabagi (C4) & S: $6^{0} 23^{\prime} 48,71^{\prime \prime}$ & $\mathrm{E}: 106^{0} 15^{\prime} 15^{\prime \prime}$ \\
\hline Jembatan Keong (C5) & S: $6^{0} 21^{\prime} 30,41^{\prime \prime}$ & E:106 $14^{\prime} 34^{\prime} 12^{\prime \prime}$ \\
\hline Jembatan II Rangkas (C6) & S: $6^{0} 20^{\prime} 54,48^{\prime \prime}$ & E: $106^{0} 14^{\prime} 50,66^{\prime \prime}$ \\
\hline Pamarayan (C7) & S: $6^{0} 15^{\prime} 38,67^{\prime \prime}$ & E: $106^{0} 16^{\prime} 41,42^{\prime \prime}$ \\
\hline Undar-Andir (C8) & S: $6^{0} 09^{\prime} 11,10^{\prime \prime}$ & $\mathrm{E}: 106^{0} 18^{\prime} 35,42^{\prime \prime}$ \\
\hline Tegal Maja (C9) & S: 6011'972' & E:106030'611"' \\
\hline Jonjing (C10) & S: $6^{0} 01^{\prime} 28^{\prime \prime}$ & E:106 ${ }^{0} 19^{\prime} 50^{\prime \prime}$ \\
\hline
\end{tabular}

Pollution index calculation results are shown in table 3

Table 3. Pollution index calculation results

\begin{tabular}{|c|c|c|c|c|c|c|c|c|c|c|}
\hline \multirow{2}{*}{ Location } & \multicolumn{2}{|c|}{ January } & \multicolumn{2}{|c|}{ February } & \multicolumn{2}{|c}{ March } & \multicolumn{2}{c|}{ April } & \multicolumn{3}{c|}{ May } \\
\cline { 2 - 13 } & PI & status & PI & status & PI & status & PI & status & PI & status \\
\hline C1 & 6 & $\mathrm{M}$ & 7,5 & $\mathrm{M}$ & 6,5 & $\mathrm{M}$ & 7,1 & $\mathrm{M}$ & 6,3 & $\mathrm{M}$ \\
\hline $\mathrm{C} 2$ & 6 & $\mathrm{M}$ & 6 & $\mathrm{M}$ & 6,5 & $\mathrm{M}$ & 6,8 & $\mathrm{M}$ & 6,5 & $\mathrm{M}$ \\
\hline $\mathrm{C} 3$ & 6,5 & $\mathrm{M}$ & 6 & $\mathrm{M}$ & 6,8 & $\mathrm{M}$ & 6,5 & $\mathrm{M}$ & 6,5 & $\mathrm{M}$ \\
\hline $\mathrm{C} 4$ & 7,6 & $\mathrm{M}$ & 6,5 & $\mathrm{M}$ & 7,5 & $\mathrm{M}$ & 6,5 & $\mathrm{M}$ & 6,5 & $\mathrm{M}$ \\
\hline $\mathrm{C} 5$ & 6,1 & $\mathrm{M}$ & 5,5 & $\mathrm{M}$ & 7,9 & $\mathrm{M}$ & 7,6 & $\mathrm{M}$ & 6,9 & $\mathrm{M}$ \\
\hline $\mathrm{C} 6$ & 5,4 & $\mathrm{M}$ & 6 & $\mathrm{M}$ & 5,4 & $\mathrm{M}$ & 5,4 & $\mathrm{M}$ & 6,1 & $\mathrm{M}$ \\
\hline $\mathrm{C} 7$ & 5,4 & $\mathrm{M}$ & 5 & $\mathrm{M}$ & 6,8 & $\mathrm{M}$ & 6,5 & $\mathrm{M}$ & 6,1 & $\mathrm{M}$ \\
\hline $\mathrm{C} 8$ & 5,5 & $\mathrm{M}$ & 5,5 & $\mathrm{M}$ & 8,5 & $\mathrm{M}$ & 5,4 & $\mathrm{M}$ & 5,5 & $\mathrm{M}$ \\
\hline $\mathrm{C} 9$ & & & 5,5 & $\mathrm{M}$ & 6 & $\mathrm{M}$ & 5,4 & $\mathrm{M}$ & 5,6 & $\mathrm{M}$ \\
\hline $\mathrm{C} 10$ & 5,5 & $\mathrm{M}$ & & & & & 5,5 & $\mathrm{M}$ & 5,5 & $\mathrm{M}$ \\
\hline
\end{tabular}


Result of pollution index calculation can describe that Ciujung River is moderately polluted. In January the highest PI is at Sabagi and the lowest PI is at Pamarayan and Jembatan II, distribution of PI January is shown in fig. 2. In February the highest PI is at Bojongmanik and the lowest PI is at Pamarayan, distribution of PI February show in fig.3

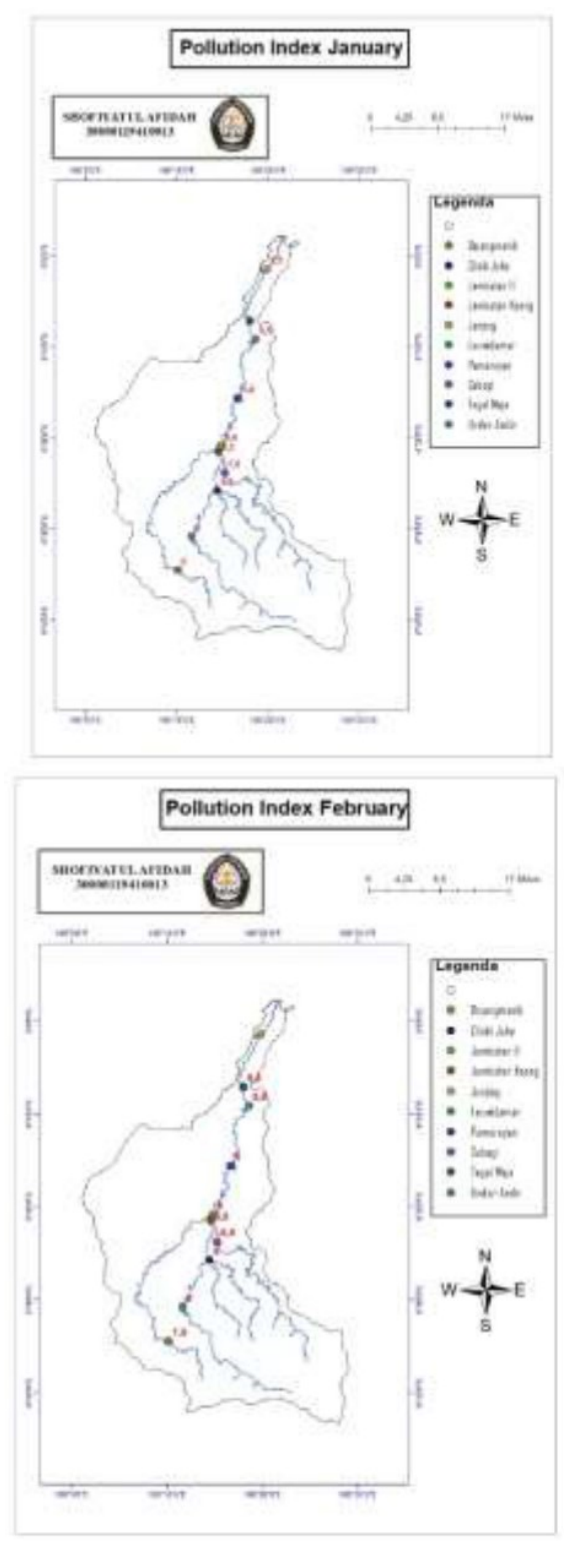

Fig.2. Pollution index January \& February

At Sabagi and Bojongmanik the highest $\mathrm{Ci} / \mathrm{Lij}$ is phenol parameter, phenol in aquatic comes from antiseptic waste water [10], industrial waste water [11] and processes of longrange atmospheric transport (LRAT) [12]. Land use in Ciujung watershed at Sabagi and Bojongmanik is household and agriculture. Domestic waste water that contain of antiseptic material is cause of high phenol at Sabagi and Bojongmanik. January and February are peak 


\section{ICENIS 2020}

of rainy season, high phenol parameter can be caused by run off from clinical waste water that contain of antiseptic material.
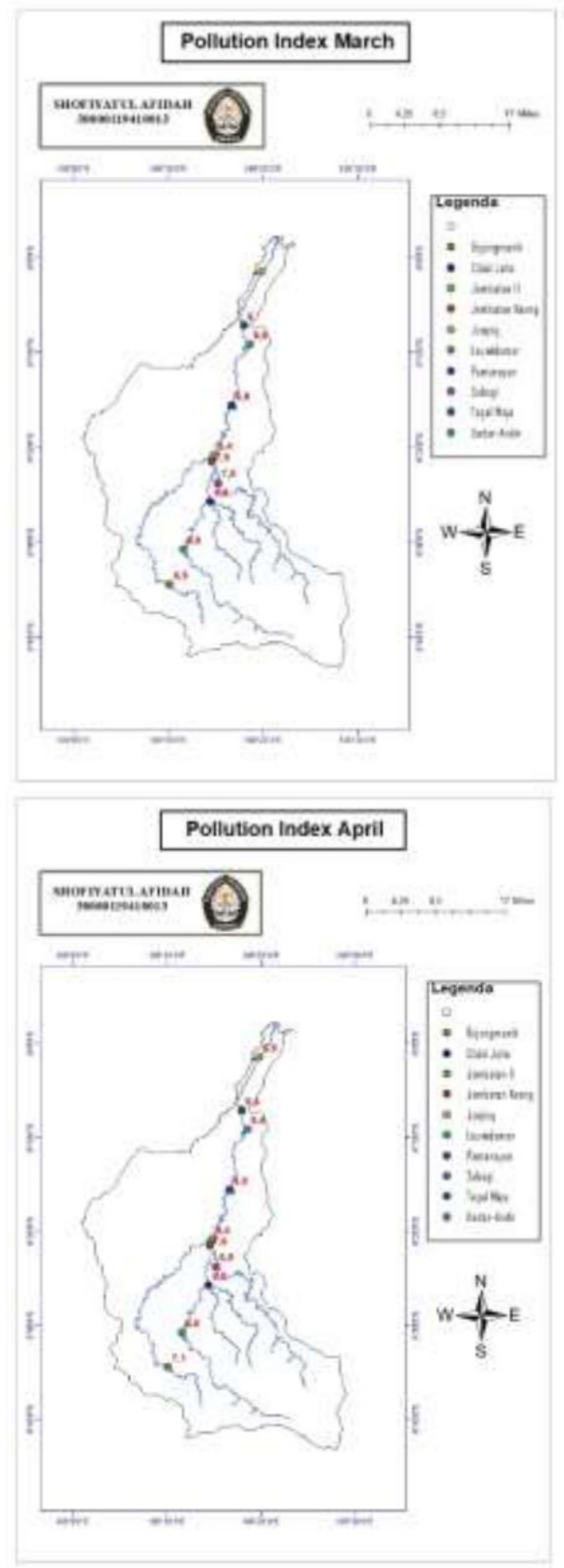

Fig.3. Pollution index March \& April

In March the highest PI is at Undar-andir and the lowest PI is at Jembatan II, distribution of PI in March show in fig.4. At Undar-andir the highest $\mathrm{Ci} / \mathrm{Lij}$ is copper $(\mathrm{Cu})$ parameter, copper in aquatic comes from maining [13], [14] stated that increased levels of heavy metals in river is generally caused by entry of industrial wate water, mining, agriculture and domestic containing heavy metals. Land use Ciujung watershed at Undar-andir is household, 
agriculture and industry. Industry around undar-andir that have waste water disposal permit in Ciujung River is PT. Indah Kiat Pulp and Paper, PT. Cipta Paperia (pulp and paper industry) and PT. Intercipta Kimia Pratama (chemical industry).

In April and May the highest PI is at Jembatan Keong, distribution of PI April and May show in fig.5 and fig.6. At Jembatan Keong the highest $\mathrm{Ci} / \mathrm{Lij}$ is phenol parameter, land use Ciujung watershed at Jembatan Keong is household, agriculture and Hospital. Domestic waste water that contain of antiseptic material and run off from Dr. Adjidarmo Hospital are cause of high phenol at Jembatan Keong.

Household and municipal discarding of sewage are source of water pollution in Indonesia that unregulated. Households dispose of waste directly into rivers routinely and the improper construction of municipal wastewater facilities leads to the disposal of untreated sewage into river waters [15]. Goverment must have a good strategy to manage Ciujung River such as tightening permits for disposal waste water to Ciujung river, make a communal wastewater treatment plant for treatment domestic waste water, and strict law enforcemant to industries that break the rules.

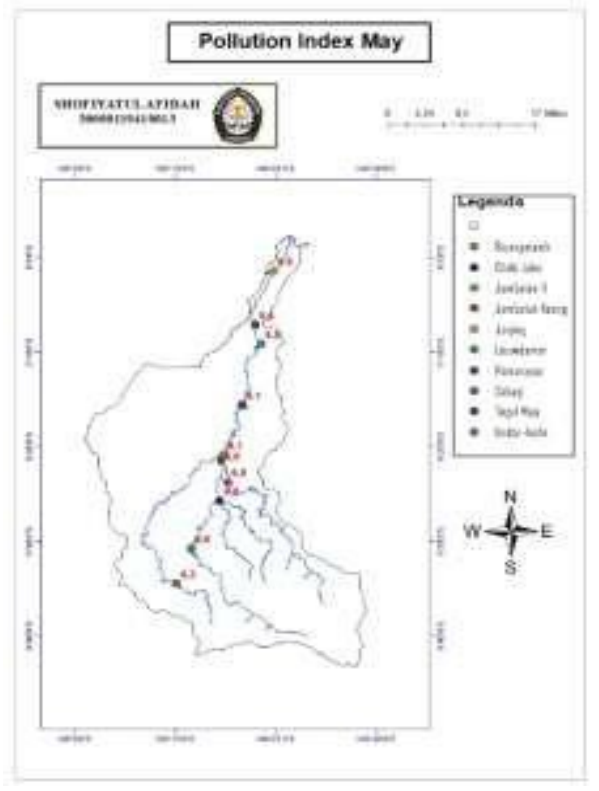

Fig. 4. Pollution Index May

\subsection{Chlorophyll-a abundance}

Chlorophyll-a abundance measured by Sentinel-2 imagery in April 2020, in April cloud cover was the smallest in 2020 (20\%). Chlorophyll-a abundance calculation results are shown in table 4:

Table 4. Chlorophyll-s abundance calculation results

\begin{tabular}{|c|c|c|c|c|c|c|c|c|c|}
\hline Jonjing & $\begin{array}{c}\text { Tegal } \\
\text { Maja }\end{array}$ & Undarandir & Pamarayan & $\begin{array}{c}\text { Jembatan } \\
\text { II }\end{array}$ & $\begin{array}{c}\text { Jembatan } \\
\text { Keong }\end{array}$ & $\begin{array}{c}\text { Sabagi } \\
\text { Jilaki } \\
\text { Jahe }\end{array}$ & $\begin{array}{c}\text { Leuwidamar } \\
\text { Bojongmanik }\end{array}$ \\
\hline 30,2063 & 24,3 & 22,85 & 38,6 & 18,97 & 18,6 & 18,65 & 31,14 & 26,93 & 25,33 \\
\hline
\end{tabular}

Range of chlorophyll-a abundance in Ciujung River between 4,91071 to 349,102 . Illustration of distribution of chlorophyll-a abundance at each sample location is shown in figure $7,8,9,10,11,12,13,14,15$, and 16 : 


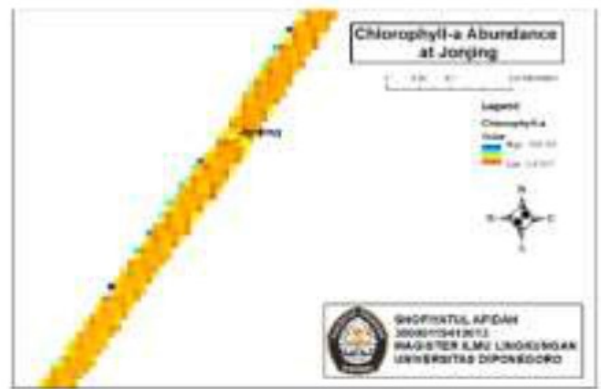

Fig.5. Chlorophyll-a abundance at Jonjing

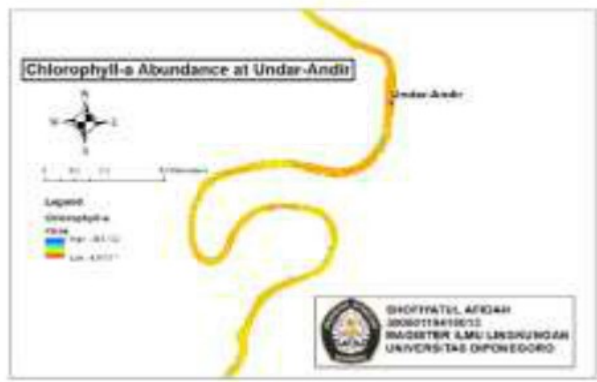

Fig.7. Chlorophyll-a abundance at Undar-andir

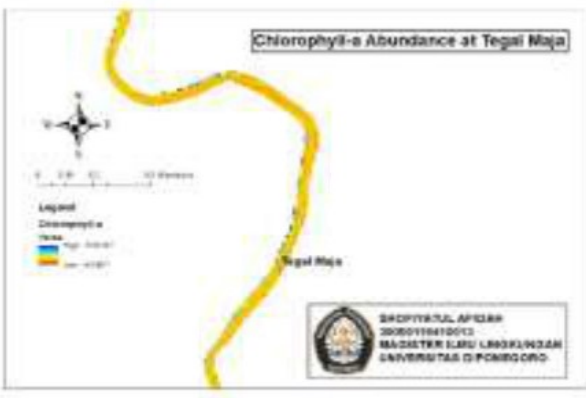

Fig.6. Chlorophyll-a abundance at Tegal Maja

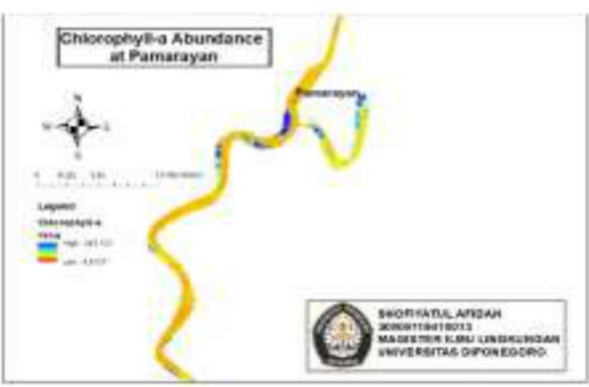

Fig.8. Chlorophyll-a abundance at Pamarayan

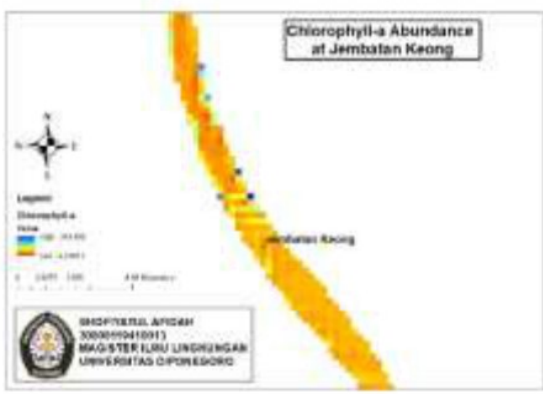

Fig. 10. Chlorophyll-a abundance at Jembatan Keong

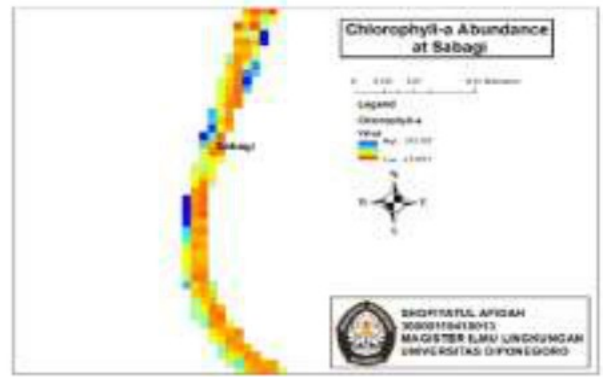

Fig.11. Chlorophyll-a abundance at Sabagi

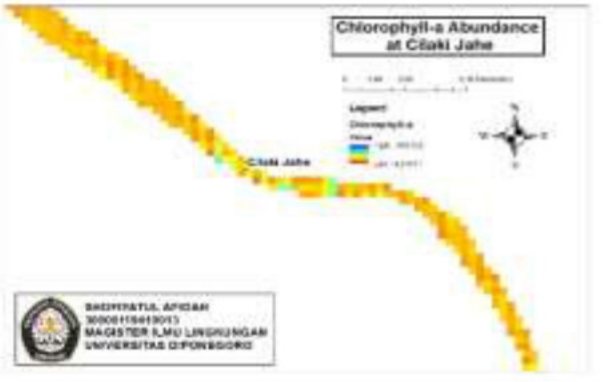

Fig.12. Chlorophyll-a abundance at Cilaki Jahe 

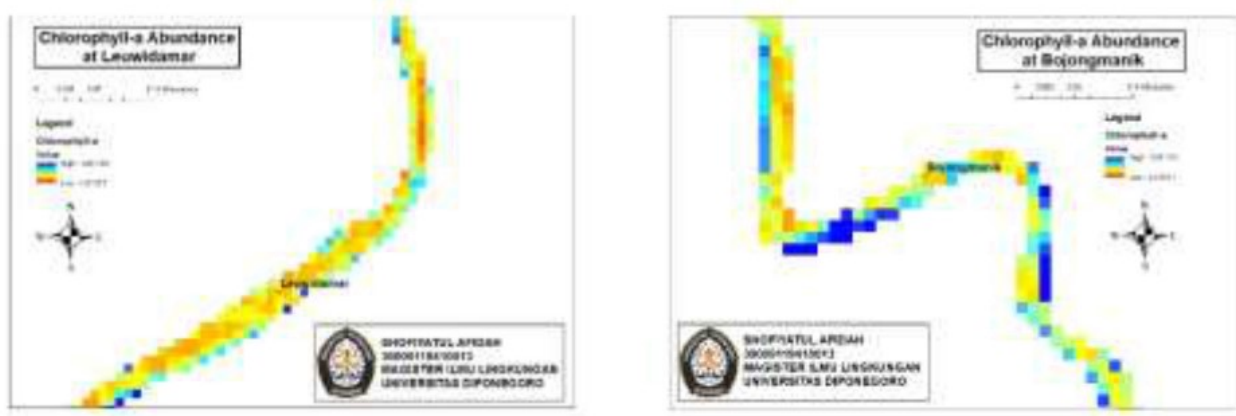

Fig.13. Chlorophyll-a abundance at Leuwidamar Fig.14. Chlorophyll-a abundance at Bojongmanik

Difference of chlorophyll-a abundance in freshwater is related to water condition and process of water mixing from botom to top [16]. The highest chlorophyll-a abundance is in Pamarayan, this location is a dam, around Pamarayan dam are rice fields and household. Chlorophyll-a abundance determine by consentration of Nitrate and Phosphate [17]. Chemical parameters that interfere with water quality are nitrates and phosphate which can be found in fertilizer and household waste content [18]. The high abundance of chlorophylla in Pamarayan is influenced by nitrates and phosphates from agriculture and households around the dam. The lowest chlorophyll-a abundance is in Jembatan Keong, around Jembatan Keong are households and agriculture. Factors that determine formation of chlorophyll are genes, light, and elements $\mathrm{N}, \mathrm{Mg}, \mathrm{Fe}$ as forming and catalyst in synthesis of chlorophyll [19]. Concentration of $\mathrm{Mg}$ and Fe in Jembatan Keong is 3,89 mg/L and 4,15 mg/L, it's lower than concentration in Pamarayan.

\section{Conclusions}

Result of pollution index calculation and chlorophyll-a abundance can describe that Ciujung River is moderately polluted. Activities in Ciujung River Basin that affect water quality Ciujung River are households, hospital, agriculture and pulp and paper industry. Goverment must have a good strategy to manage Ciujung River such as tightening permits for disposal waste water to Ciujung river, make a communal wastewater treatment plant for treatment domestic waste water, and strict law enforcemant to industries that break the rules.

\section{References}

[1] A. K. Hua, Identifying the source of pollutants in Malacca river using GIS approach, Appl. Ecol. Environ. Res., vol. 15, no. 4, pp. 571-588, (2017)

[2] Y. Utomo, B. Priyono, and S. Ngabekti, Saprobitas Perairan Sungai Juwana Berdasarkan Bioindikator Palnkton, Unnes J. Life Sci., vol. 2, no. 1, pp. 28-35, (2013)

[3] Y. Fu, S. Xu, C. Zhang, and Y. Sun, Spatial downscaling of MODIS Chlorophyll-a using Landsat 8 images for complex coastal water monitoring, Estuar. Coast. Shelf Sci., vol. 209, no. July (2017)

[4] J. He, Y. Chen, J. Wu, D. A. Stow, and G. Christakos, Space-time chlorophyll-a retrieval in optically complex waters that accounts for remote sensing and modeling uncertainties and improves remote estimation accuracy, Water Res., vol. 171, p. 115403,(2020) 
[5] O. N. Kimambo, H. Chikoore, J. R. Gumbo, and T. A. M. Msagati, Retrospective analysis of Chlorophyll-a and its correlation with climate and hydrological variations in Mindu Dam, Morogoro, Tanzania, Heliyon, vol. 5, no. 11, p. e02834, (2019)

[6] H. Effendi, Simulasi Penentuan Indeks Pencemaran dan Indeks Kualitas Air ( NSF$W Q I),(2015)$.

[7] L. Guo, J. Luo, M. Yuan, Y. Huang, H. Shen, and T. Li, Science of the Total Environment The in fl uence of urban planning factors on PM 2.5 pollution exposure and implications: A case study in China based on remote sensing, LBS, and GIS data, Sci. Total Environ., vol. 659, pp. 1585-1596, (2019)

[8] I. Gupta, A. Kumar, C. Singh, and R. Kumar, Detection and Mapping of Water Quality Variation in the Godavari River Using Water Quality Index, Clustering and GIS Techniques, J. Geogr. Inf. Syst., vol. 07, no. 02, pp. 71-84, (2015)

[9] J. Chen, W. Zhu, Y. Q. Tian, Y. Zheng, and L. Huang, Remote estimation of colored dissolved organic matter and chlorophyll-a in Lake Huron using Sentinel-2 measurements, J. Appl. Remote Sens., vol. 11, no. 3, pp. 036007-1-036007-15 (2017)

[10] M. Komarudin, Analisis Daya Tampung Beban Pencemar Menggunakan Model Numerik dan Spasial - Studi Kasus: Sungai Pesanggrahan Segmen Kota Depok Jawa Barat, Institut Pertanian Bogor, (2015)

[11] D. Marganingrum, D. Roosmini, P. Pradono, and A. Sabar, Diferensiasi Sumber Pencemar Sungai Menggunakan Pendekatan Metode Indeks Pencemaran (IP ) (

Studi Kasus : Hulu DAS Citarum ), Ris. Geol. dan Pertamb., vol. 23, no. 1, pp. 3748, (2013)

[12] S. Lehmann-Konera, W. Kociuba, S. Chmiel, Ł. Franczak, and Ż. Polkowska, Concentrations and loads of DOC, phenols and aldehydes in a proglacial arctic river in relation to hydro-meteorological conditions. A case study from the southern margin of the Bellsund Fjord - SW Spitsbergen, Catena, vol. 174, no. October (2018)

[13] S. W. Tjokrokusumo, Upaya mitigasi pencemaran laut dengan, vol. 7, no. 2, pp. 180-189, (2006)

[14] S. Yudo, Kondisi Pencemaran Logam Berat Di Perairan Sungai Dki Jakarta, J. Air Indones., vol. 2, no. 1, pp. 1-15, (2006)

[15] T. Garg, S. E. Hamilton, J. P. Hochard, E. P. Kresch, and J. Talbot, (Not so) gently down the stream: River pollution and health in Indonesia, J. Environ. Econ. Manage., vol. 92, pp. 35-53, (2018)

[16] N. G. Adani, M. R. Muskanonfola, and I. B. Hendrarto, Kesuburan Perairan Dintinjau dari Kandungan Klorofil-a Fitoplankton: Studi Kasus di Sungai Wedung, Demak, Manag. Aquat. Resour., vol. 2, no. 4, pp. 38-45, (2013)

[17] M. S. Ayuningsih, I. B. Hendrarto, and P. W. Purnomo, Distribusi Kelimpahan Fitoplankton dan Klorofil-a di Teluk Sekumbu Kabupaten Jepara: Hubungannya dengan KandunganNitrat dan Fosfat di Perairan, Manag. Aquat. Resour., vol. 3, no. 2, pp. 138-147, (2014)

[18] C. Patricia, W. Astono, and D. Irvindiaty Hendrawan, Kandungan nitrat dan fosfat di sungai ciliwung, Semin. Nas. Cendekiawan, vol. 4, pp. 179-185, (2018)

[19] M. A. Putri, S. Wulandari, and F. LN, Chlorophyll Content Of Dominant Plant in Post-Fire Peatlands and Its Use For The Design of Student Worksheet on Biology in Senior High School, pp. 1-12. 